\title{
PENGEMBANGAN BAHAN AJAR ELEKTRONIK SCIENCE FLASHBOOK MATA PELAJARAN IPA KELAS VIII SMP PADA MATERI POKOK PARTIKEL
}

\author{
Alim Al Ayubi Syam ${ }^{1}$, Muhammad Danial ${ }^{2}$, Sudding $^{3}$ \\ ${ }^{1}$ Guru Kimia SMAN 1 Bambaira \\ ${ }^{2,3}$ Dosen Program Pascasarjana Universitas Negeri Makassar \\ Email: alim.al.ayubi@gmail.com
}

\begin{abstract}
ABSTRAK
Penelitian ini bertujuan mengembangkan dan menghasilkan bahan ajar elektronik Science Flashbook mata pelajaran IPA. Penelitian pengembangan ini menggunakan model pengembangan Plomp yang terdiri dari lima fase yaitu fase investigasi awal, fase desain, fase realisasi/konstruksi, fase tes, evaluasi dan revisi, dan fase implementasi. Subjek uji coba produk pengembangan ini adalah siswa kelas VIII SMPIT Al Biruni Makassar dengan jumlah peserta didik 20 orang. Dalam penelitian ini, teknik pengumpulan data untuk mengukur kevalidan, kepraktisan dan keefektifan yang digunakan adalah angket respon, lembar validasi, lembar pengamatan, dan lembar tes belajar. Teknik analisis data yang digunakan yaitu analisis statistik deskriptif. Hasil penelitian menunjukkan semua item dan aspek yang diukur yaitu penilaian kevalidan media memperoleh kriteria valid dengan nilai rata-rata 3,83, penilaian kepraktisan media adalah praktis dengan persentase $93,75 \%$ pada total kriteria "Sangat Setuju" dan "Setuju". Hasil belajar peserta didik adalah $80 \%$ dan 8 aktivitas yang diamati terlaksana dengan baik. Hasil tersebut menujukkan bahwa bahan ajar elektronik Science Flashbook mata pelajaran yang dikembangkan memiliki kategori valid, praktis dan efektif, sehingga dapat disimpulkan bahan ajar elektronik Science Flashbook mata pelajaran IPA yang dihasilkan layak dijadikan sebagai media dan sumber pembelajaran.
\end{abstract}

Kata kunci : pengembangan, bahan ajar elektronik, IPA, partikel, plomp

\begin{abstract}
This research is about to develop and product the electronic teaching science book. The development research using development model of Plomp which consist of five phases, they are investigation, design, realization/construction, test, evaluation and revision, and implementation. Subject test for development product is $8^{\text {th }}$ Grade student of Islamic Junior High School Al Biruni Makassar which consist of 20 students. Data were collected by measuring validity, practices, and effectivity using questionnaire, validity sheet, observation sheet, and evaluating sheet. Data were analyzed by using descriptive statistics analysis. The results of the study reveal all of the items and the aspects measured are the assessment of media validity obtained valid criteria with value 3,83 , the assessment of media practicality was practical with percentage 93,75 int total of "Very Agree" and "Agree". The result of student test was $80 \%$ and 8 activity that observed were achieved. The result indicates that Science Flashbook conducted was valid, practical, and effective. The conclusion is the development of Science Flashbook as electronic teaching science book is feasible as learning media and learning sources.
\end{abstract}

Keywords: development, electronic learning material, science, particle, plomp. 


\section{PENDAHULUAN}

Kelangsungan hidup (survival) bangsa Indonesia di masa depan sangat tergantung pada teknologi yang dimilikinya. Selain itu, yang tampak tidak langsung tapi sangat menentukan kelangsungan hidup (survival) bangsa adalah pendidikan (Besari, 2008: 338-339). Hal ini berarti kebutuhan paling dasar bangsa Indonesia ditinjau berdasarkan alat survival adalah teknologi dan pendidikan. Demi mengoptimalkan alat survival tersebut, seyogianya teknologi dan pendidikan dilaksanakan beriringan, saling menopang satu sama lain dalam suatu wadah yang dapat memaksimalkan potensi kebermanfaatannya.

Memanfaatkan dan menggunakan teknologi semaksimal mungkin pada pelaksanaan proses-proses pendidikan bertujuan untuk menopang pendidikan serta mengikuti perkembangan zaman yang semakin maju. Hal yang dimaksud ini berlandaskan pada kebijakan yang diatur dalam Undang-Undang Dasar 1945 pada pasal 31 ayat 5 yaitu pemerintah memajukan ilmu pengetahuan dan teknologi dengan menjunjung tinggi nilai-nilai agama dan persatuan bangsa untuk kemajuan peradaban serta kesejahteraan umat manusia.

Merujuk dari data implementasi pendidikan di Indonesia berdasarkan Global Education Monitoring Report (GEM Report) yang diterbitkan oleh UNESCO tahun 2016 menunjukkan bahwa kualitas dan mutu pendidikan di Indonesia tergolong rendah. Hal tersebut berdasarkan pada data Kemampuan Baca Tulis Skala Berkelanjutan yang masih rendah dan data Environmental Knowledge (Pengetahuan Lingkungan) yang tergolong paling rendah yaitu berada pada level-D dari beberapa negara di benua Asia. Hal ini senada dengan data performa pelajar Indonesia berdasarkan Program for International Student Assessment (PISA) 2015 yang hasilnya dikeluarkan oleh The Organization for Economic Co-operation and Development (OECD) pada Desember 2016 menunjukkan kemampuan pengetahuan umum dari skala 1000 berada pada rentang 403 (dibawah persentase 50\%), kemampuan membaca dari skala 600 pada rentang 397, dan kemampuan matematika pada rentang 386 dari skala 600. Torehan nilai tersebut menempatkan Indonesia pada peringkat 62 dari 70 negara, bahkan tertinggal jauh dibanding negara bagian Asia lainnya seperti Singapura pada peringkat pertama, Jepang pada peringkat kedua, dan Vietnam pada peringkat kedelapan. Belum lagi jika ditambahkan dengan data analisis peringkat oleh Best Countries for Education dan dilaporkan oleh U.S News pada Maret 2017 yang menunjukkan bahwa Indonesia berada pada peringkat 52 dari 80 negara yang berpartisipasi. Peringkat ini juga berada di bawah Malaysia yang menduduki peringkat 43. Hasil ini dipengaruhi oleh bagaimana dan seperti apa kurikulum yang berlaku khususnya di Indonesia.

Perkembangan kurikulum tidak terlepas dari usaha pemerintah, pelaksana pendidikan, dan masyarakat demi tercapainya tujuan bersama yang diinginkan. Hal ini diharapkan dapat menjadi solusi awal dalam mengatasi rendahnya kualitas proses dan hasil pendidikan di Indonesia yang berakibat pada rendahnya rata-rata kualitas sumber daya manusia Indonesia dalam konteks persaingan global dan regional (Asfiati, 2016: 24).

Pemanfaatan perangkat Teknologi Informasi dan Komunikasi (TIK) dalam dunia pendidikan Indonesia seringkali hanya digunakan untuk membantu kegiatan administrasi di sekolah saja, padahal perangkat Teknologi Informasi dan Komunikasi (TIK) dapat dimanfaatkan lebih jauh untuk meningkatkan kualitas pembelajaran di ruang kelas dengan cara mengintegrasikannya ke dalam kurikulum yang ada (Gora dan Sunanto, 2010: 22).

Tenaga pendidik memegang peranan penting sebagai ujung tombak implementasi kurikulum. Merujuk pada kebijakankebijakan pemerintah dalam UUD 1945 yang dikemukakan sebelumnya mengenai penggunaan teknologi dalam pendidikan, tenaga pendidik dituntut untuk mampu menggunakan dan memanfaatkan Teknologi Informasi dan Komunikasi (TIK) dalam 
proses pembelajaran. Hal ini dimaksudkan sebagai suatu upaya inovatif dalam peningkatan kualitas SDM.

Teknologi Informasi dan

Komunikasi (TIK) meliputi segala hal yang berkaitan dengan proses, penggunaan sebagai alat bantu, manipulasi dan pengelolaan informasi. Sedangkan teknologi komunikasi adalah segala sesuatu yang berkaitan dengan penggunaan alat bantu untuk memproses dan mentransfer data dari perangkat yang satu ke lainnya. Salah satu perangkat TIK yang dimaksudkan adalah alat bantu seperti komputer yang di dalamnya terdapat software, akses jaringan, dan aplikasi-aplikasi dengan berbagai macam fungsi praktis (Suryana, 2012: 8).

Materi IPA pada tingkat Sekolah Menengah Pertama (SMP) merupakan mata pelajaran yang tidak sedikit siswa menganggap materinya sulit dan membutuhkan proses nalar yang lebih. Oleh sebab itu, perlu dikembangkan suatu integrasi inovasi TIK yang dapat membantu dan memudahkan siswa dalam belajar IPA. Hal ini merupakan tugas dan tantangan bagi tenaga pendidik/guru dalam menciptakan suasana belajar yang menyenangkan dengan mengintegrasikan TIK dalam kegiatan pembelajaran. Berbagai perangkat pembelajaran yang bersifat operasional seperti RPP, buku paket dan media merupakan keperluan guru dalam kegiatan pembelajaran. Integrasi teknologi dalam kegiatan pembelajaran dianggap sangat perlu agar dapat memudahkan siswa dalam belajar serta menumbuh kembangkan minat siswa terhadap Ilmu Pengetahuan dan Teknologi (IPTEK). Dengan teknologi, siswa dapat belajar secara menyenangkan dan efisien sebab akan banyak berinteraksi dengan warna, gambar, suara, video, dan program-program yang dapat membantu proses pembelajaran.

Pada umumnya, guru di dalam kelas berpedoman pada bahan ajar seperti buku cetak di mana buku cetak IPA SMP adalah suatu bahan ajar bersifat monoton berisikan materi-materi IPA yang tertera dalam bentuk halaman demi halaman sehingga siswa menjadi malas membacanya. Masalah serupa terbukti di Sekolah Menengah Pertama Islam Terpadu Al Biruni Makassar, di mana pada hasil observasi ditemukan bahwa siswa cenderung malas membaca buku paket IPA yang tampilannya monoton dan tidak berwarna serta penyampaian informasi yang kurang menarik. Siswa hanya menunggu penjelasan dari guru dan tidak bersemangat untuk mempelajarinya sendiri melalui sumber-sumber bacaan. Oleh karena itu, untuk mengatasi hal tersebut penulis mengusulkan sebuah bahan ajar baru berbasis media TIK yang lebih inovatif, menarik, dan interaktif yang dikemas dalam bentuk bahan ajar elektronik IPA.

Bahan ajar elektronik didefinisikan sebagai materi pembelajaran yang dibuat menggunakan alat bantu teknologi informasi dan komunikasi sehingga menghasilkan sebuah paket materi pembelajaran yang meramu berbagai macam media, memiliki interaktifitas, dan penyajiannya terintergrasi dengan metode pembelajaran (Batubara, 2018: 17).

Beberapa hal yang menjadi manfaat utama pada pengembangan bahan ajar elektronik bagi siswa adalah (1) sebagai alternatif media pembelajaran, menumbuhkan minat belajar siswa melalui konten multimedia yang menarik, (3) mempermudah proses memahami materi pelajaran melalui konten suara, gambar, dan video (4) ukurannya kecil dan dapat disimpan dalam berbagai media penyimpanan elektronik, (5) terdapat fitur pencarian sehingga siswa dapat dengan mudah menemukan kata atau istilah dengan cepat yang mana fitur ini bermanfaat dalam pengkajian literatur, (6) dapat dimanfaatkan oleh siswa yang memiliki keterbatasan pandangan dalam membaca dalam hal ini huruf-huruf dalam bahan ajar elektronik dapat diperbesar sesuai kebutuhan, (7) bahkan dapat digunakan oleh penyandang tunanetra dengan memanfaatkan fitur komputer text to speech synthesizer. Dalam hal ini riset masih dibutuhkan untuk 
membuat sistem pembacaan yang lebih bagus (Basman, 2017: 6-7).

Penelitian terkait pengembangan bahan ajar elektronik pernah dilakukan oleh Wijayanto pada tahun 2016 terkait Pengembangan Buku Sekolah Elektronik berbasis Portable Document Format di mana diperoleh rata-rata hasil belajar yang lebih baik pada suatu kelas eksperimen $(83,44)$ yang menggunakan bahan ajar berbentuk buku elektronik dibanding dengan kelas kontrol $(79,33)$.

Penelitian lain terkait bahan ajar elektronik juga dilakukan oleh Rusnilawati pada tahun 2017 tentang Pengembangan bahan Ajar Elektronik (BAE) Berbantuan Flipbook berbasis Keterampilan Pemecahan Masalah Dengan Pendekatan CTL Pada Pembelajaran Matematika Kelas V Sekolah Dasar dan membuahkan hasil memuaskan dalam kepraktisan yaitu pada kateogiru "baik" oleh penilaian peserta didik dan "sangat baik" oleh penilaian pendidik yang berakibat pada ketuntasan hasil kemampuan pemecahan masalah peserta didik mencapai 92,9\%.

Pengembangan media atau perangkat pembelajaran, dalam hal ini bahan ajar elektronik membutuhkan pedoman untuk menghasilkan suatu pengembangan media yang berkualitas dan membantu tercapainya tujuan pembelajaran. Terdapat berbagai macam model penelitian pengembangan yang telah dikemukakan oleh ahli pendidikan, salah satunya adalah model pengembangan Plomp. Pemilihan model pengembangan Plomp disebabkan karena model ini dalam Rochmad (2012: 65) dipandang lebih luwes dan fleksibel dibandingkan dengan model pengembangan lainnya, karena setiap langkahnya memuat kegiatan pengembangan yang dapat disesuaikan dengan karakteristik penelitiannya.

Tujuan penelitian pengembangan adalah mendukung pengembangan hasil prototype (memasukkan fakta empiris untuk mendukung efektivitasnya dan menggunakan metodologi umum untuk mendesain dan mengevaluasi produk. Model pengembangan Plomp terdiri dari lima fase, yaitu: (1) fase investigasi awal; (2) fase perencanaan; (3) fase realisasi (konstruksi); (4) fase evaluasi, tes, dan revisi; serta (5) fase implementasi (Plomp, 2013: 11).

Dengan berpedoman pada model pengembangan Plomp, guru dapat mengolah informasi, materi, dan ilmu yang terdapat pada buku paket IPA Kelas VIII SMP dalam pengembangan ini, khususnya pada Materi Pokok Partikel: Atom, Ion, dan Molekul, menjadi suatu bahan ajar bernama Science Flashbook yaitu pengembangan program aplikasi bahan ajar elektronik. Science Flashbook merupakan aplikasi inovatif, komunikatif, dan interaktif yang dikembangkan oleh penulis di mana program aplikasi ini memiliki berbagai kelebihan yang dapat meningkatkan minat belajar siswa, menambah pengetahuan siswa mengenai teknologi, melatih kecakapan siswa dalam menggunakan teknologi, serta memudahkan transfer ilmu IPA disebabkan penyajian Materi Pokok Partikel yang disajikan dalam bentuk animasi 2D (dua dimensi) dan 3D (tiga dimensi) sehingga materi dan gambar yang tadinya bersifat monoton pada buku paket menjadi lebih modern, menyenangkan, dan komunikatif.

Berdasarkan uraian di atas, maka penulis mengangkat judul penelitian "Pengembangan Bahan Ajar Elektronik Science Flashbook Mata Pelajaran IPA Kelas VIII SMP Pada Materi Pokok Partikel."

\section{METODE PENELITIAN}

Penelitian ini merupakan penelitian jenis pengembangan (Research and Development) yang bertujuan untuk mengembangkan bahan ajar elektronik Science Flashbook mata pelajaran IPA kelas VIII SMP pada Materi Pokok Partikel.

Penelitian ini diujicobakan pada peserta didik kelas VIII SMPIT Al Biruni Makassar pada semester ganjil tahun pelajaran 2018/2019. Jumlah peserta didik sebanyak 20 orang. 
Adapun prosedur penelitian ini dilaksanakan berdasarkan pengembangan bahan ajar elektronik Science Flashbook mata pelajaran IPA Kelas VIII SMP yang mengadaptasi model pengembangan Plomp melalui beberapa tahapan.

Data yang akan dikumpulkan dengan menggunakan instrumen-instrumen berupa lembar validasi, angket, lembar observasi, dan tes hasil belajar selanjutnya akan dianalisis secara kuantitatif untuk mengetahui kualitas bahan ajar elektronik Science Flashbook mata pelajaran IPA Kelas VIII SMP yang dihasilkan. Teknik analisis data terdiri dari: Kevalidan, Respon Pendidik dan Peserta Didik, Aktivitas Pendidik dan Peserta Didik, dan Tes Hasil Belajar.

\section{HASIL DAN PEMBAHASAN}

\section{Hasil Penelitian}

\section{Proses Pengembangan Bahan Ajar Elektronik Science Flashbook Mata Pelajaran IPA}

\section{a. Fase Investigasi Awal}

Hasil kegiatan investigasi awal dideskripsikan dalam beberapa fase di bawah ini.

Dari hasil observasi diperoleh gambaran bahwa (1) guru dalam mengajar masih sering menggunakan model dan metode yang bersifat konvensional. (2) Sarana dan prasarana yang ada masih kurang dimanfaatkan sehingga kemampuan guru dalam mengajar tidak maksimal yang berdampak pada proses penerimaan informasi oleh peserta didik yang juga tidak maksimal. Metode mengajar yang monoton membuat banyak peserta didik kurang memerhatikan pembelajaran sehingga banyak peserta didik memiliki capaian hasil belajar yang rendah. Melihat fenomena yang ada dan setelah melakukan wawancara singkat dengan pendidik diperoleh informasi bahwa keterbatasan waktu mempersiapkan media dan bahan ajar membuat pendidik kesulitan melaksanakan pembelajaran yang inovatif. Pendidik mengharapkan ada sebuah gagasan dan media inovatif yang dapat membuat pendidik mudah melaksanakan pembelajaran tanpa harus kehilangan waktu mempersiapkan bahan ajar yang rumit.

Di Sekolah Menengah Pertama Islam Terpadu Al Biruni juga telah dilengkapi dengan ruangan komputer dan terdapat lima buah LCD yang disiapkan sekolah untuk kebutuhan pembelajaran yang jarang digunakan dan hanya sering digunakan untuk kegiatan sekolah bersifat ekstrakurikuler.

Kurikulum yang digunakan di SMP Islam Terpadu Al Biruni Makassar pada kelas VIII adalah kurikulum KTSP ketika penelitian ini dilaksanakan. Proses pembelajaran dengan kurikulum ini tidak seperti di kurikulum 2013 yang mengepankan student center sehingga perlu media atau model pembelajaran yang dapat menunjang penyampaian informasi oleh pendidik terhadap peserta didik. Berdasarkan observasi lapangan, $70 \%$ siswa kelas VIII SMPIT Al Biruni Makassar telah memiliki perangkat laptop sehingga perlu kesadaran pendidik untuk memanfaatkan ketersediaan sarana pribadi ini agar terwujud pembelajaran yang lebih bermakna.

Adapun kompetensi dasar dan indikator pembelajaran IPA materi partikel disajikan pada Tabel 4.1.

Tabel 4.1 Kompetensi Dasar dan Indikator Materi Partikel

\begin{tabular}{|c|l|}
\hline $\begin{array}{c}\text { Kompetensi Dasar } \\
\text { 3.1 Menjelaskan } \\
\text { konsep atom, } \\
\text { ion, dan } \\
\text { molekul }\end{array}$ & \multicolumn{1}{|c|}{ Indikator } \\
& $\begin{array}{l}\text { Mendefinisikan } \\
\text { pengertian partikel } \\
\text { materi (atom, ion, } \\
\text { dan molekul). } \\
\end{array}$ \\
$\begin{array}{l}\text { Memberikan contoh } \\
\text { materi tertentu yang } \\
\text { terdiri atas ion-ion. }\end{array}$ \\
$\begin{array}{l}\text { Menghubungk } \\
\text { an konsep } \\
\text { atom, ion, dan } \\
\text { molekul }\end{array}$ & $\begin{array}{l}\text { Menjelaskan } \\
\text { hubungan atom, ion } \\
\text { dan molekul } \\
\text { Mendeskripsikan } \\
\text { komponen penyusun }\end{array}$ \\
\hline
\end{tabular}




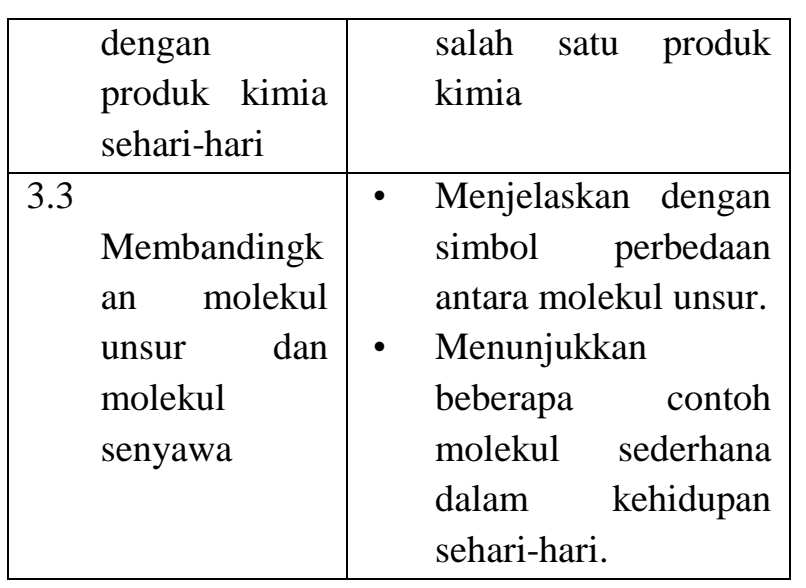

\section{b. Fase Desain}

Adapun media pembelajaran berupa bahan ajar elektronik yang dihasilkan menggunakan Adobe Indesign CS6. Bahan ajar elektronik yang dirancang diberi nama Science Flashbook.

\section{1) Penyempurnaan Konsep (Concept)}

Berdasarkan teori Luther dalam pengembangan media, hal pertama yang dilakukan adalah menyempurnakan konsep media dalam hal ini bahan ajar elektronik yang diberi nama Science Flashbook sebuah bahan ajar elektronik mata pelajaran IPA kelas VIII SMP. Pembuatan Science Flashbook menggunakan Adobe Indesign CS6 dengan tampilan awal yang dilengkapi dengan alat yang lengkap mulai dari wadah membuat halaman buku elektronik, membuat teks, memasukkan dan menggabungkan gambar, video, dan musik serta berbagai alat lain yang dapat digunakan untuk mempercantik tampilan Science Flashbook seperti yang diperlihatkan pada Gambar 4.1.

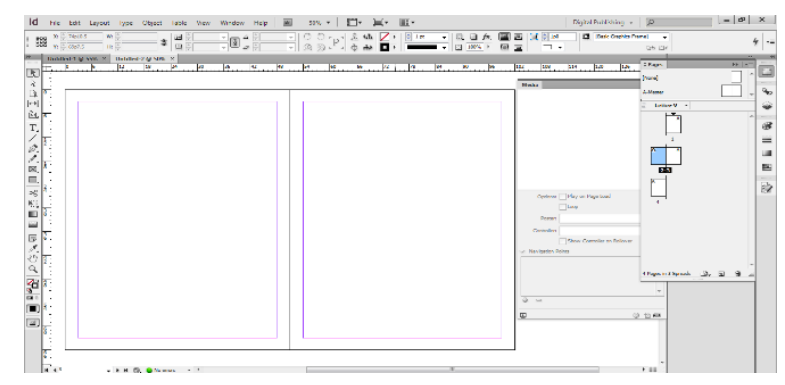

Gambar 4.1 Tampilan Awal Aplikasi Adobe Indesign CS6
2) Menyusun Desain (Design) dan Penyatuan Bahan (Material Collecting)

Bagian pertama yang dihasilkan pada pembuatan Science Flashbook adalah desain sampul buku. Di desain sampul terdapat video terkait alam, keterangan kurikulum, subjek buku, kelas, serta terdapat tombol navigasi yang memudahkan untuk menuju ke halaman selanjutnya. Terdapat pula tombol untuk menjalankan audio, tombol jeda, dan tombol memberhentikannya (Gambar 4.2).

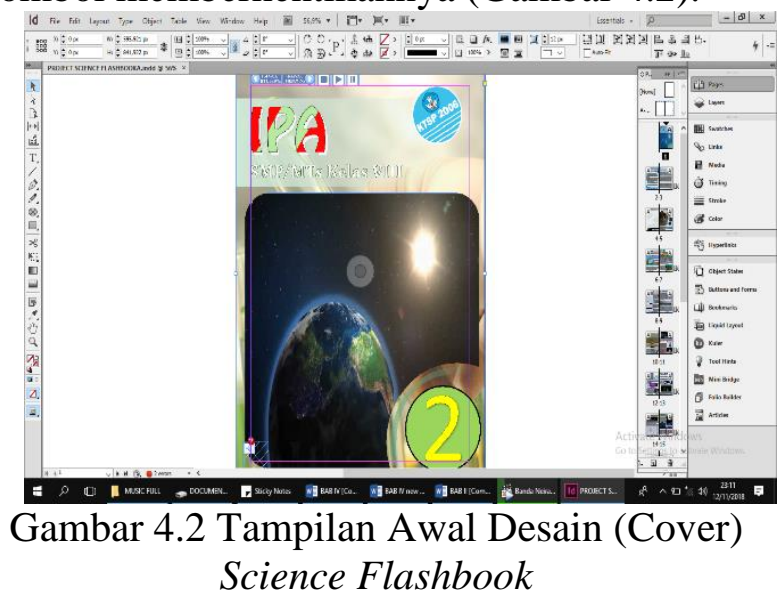

Pada halaman setelah sampul terdapat halaman yang digunakan untuk mendesain kata pengantar, daftar isi, sampul bab, kemudian isi materi

Pada tampilan materi terdapat konsep yang ditampilkan dengan gambar yang meriah dan menarik siswa untuk termotivasi membaca. Terdapat pula video yang melengkapi teori dan konsep pada materi yang ditampilkan. Tombol navigasi berada pada bagian bawah yang dapat membantu pengoperasian aplikasi. Selain itu, buku elektronik ini akan sangat efektif jika digunakan pada perangkat layer sentuh karena dapat bertindak sebagaimana buku pada umumnya yang halamannya dapat dibuka menggunakan jari.

Pada akhir bab di Science Flashbook terdapat soal evaluasi bab berupa pilihan ganda yang cara menjawabnya cukup dengan mengklik jawaban yang menurut peserta didik benar.

Pada tahap ini Prototipe 1: bahan ajar elektronik Science Flashbook mata pelajaran IPA kelas VIII SMP. 


\section{c. Fase Ralisasi/Konstruksi}

Aplikasi Science Flashbook

diletakkan di dalam sebuah folder bersama buku petunjuk penggunaannya dengan format $p d f$. Secara keseluruhan, hasil rancangan buku elektronik Science Flashbook disajikan dalam Tabel 4.2.

Tabel 4.2 Hasil Rancangan Bahan ajar Elektronik Science Flashbook

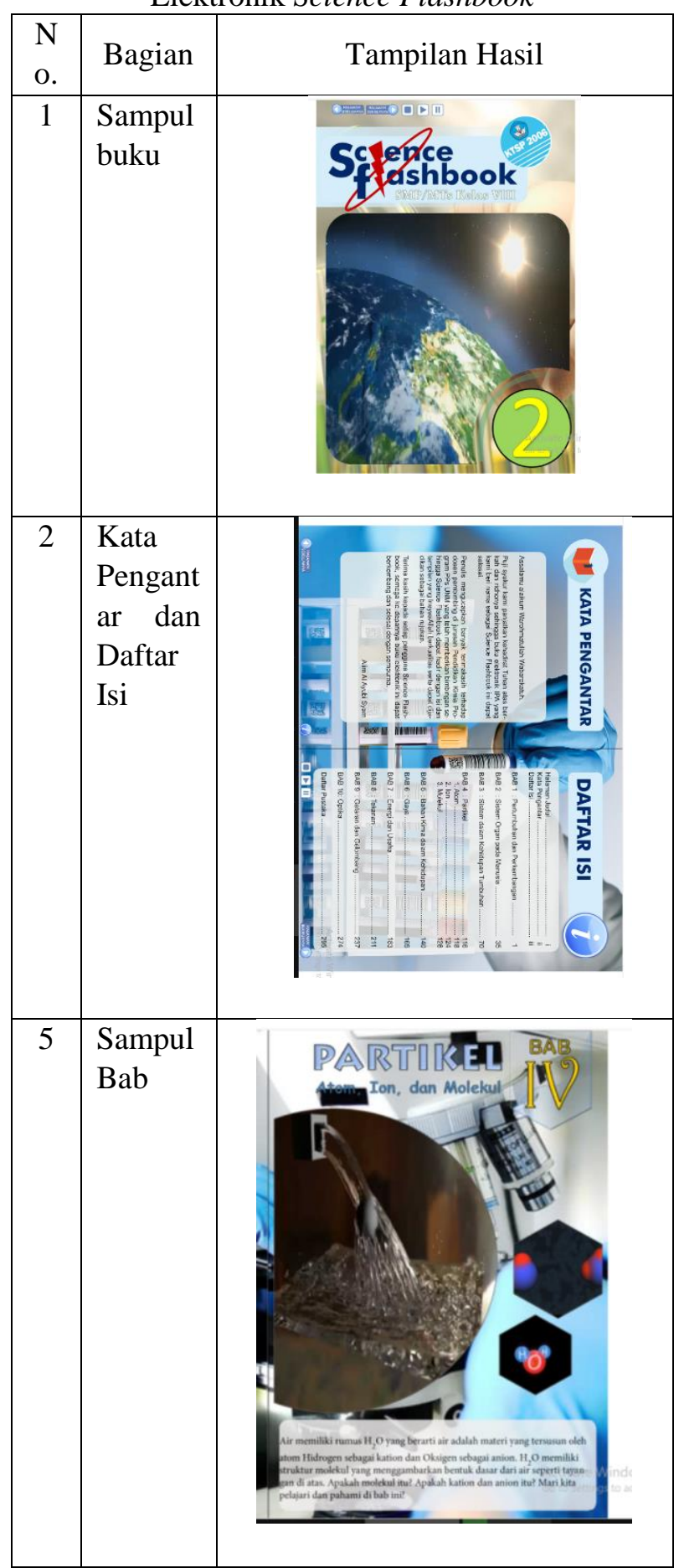

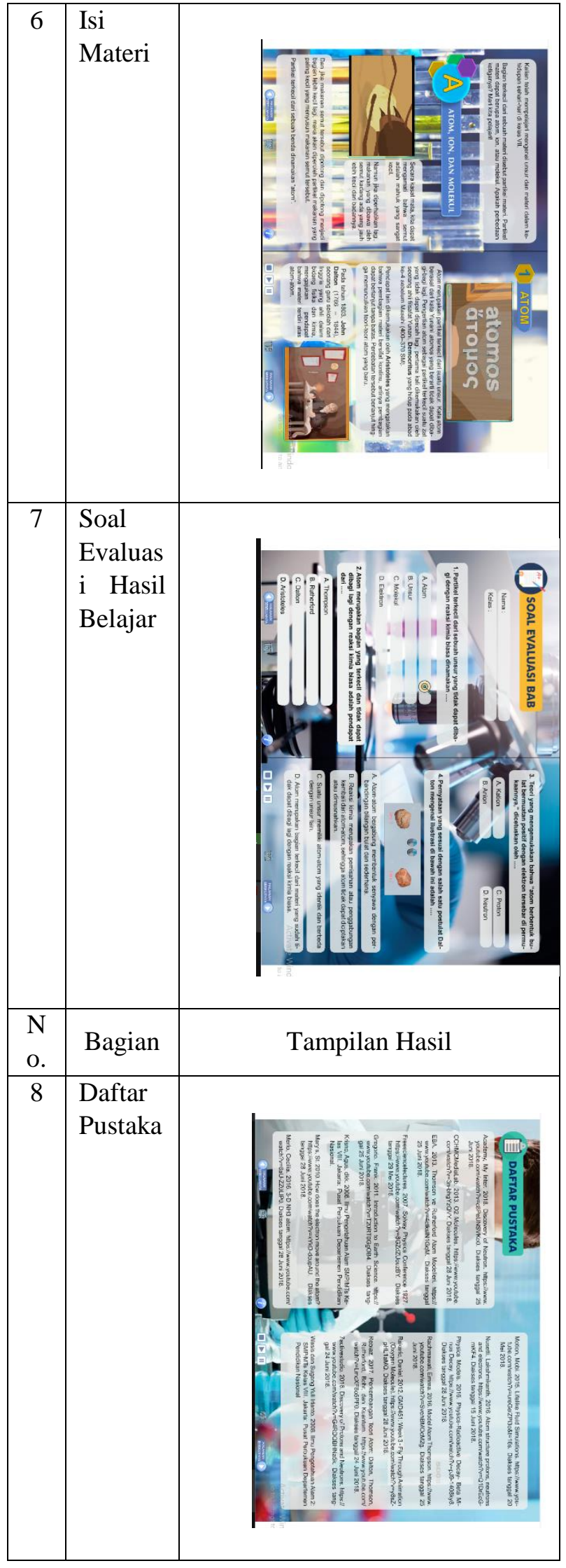


Pada tahap ini dilakukan testing alpha yaitu pengujian dari sisi pengembang bersama validator dengan melakukan validasi tahap 1 sehingga diperoleh Prototipe 2: bahan ajar elektronik Science Flashbook mata pelajaran IPA kelas VIII SMP.

\section{d. Fase Tes, Evaluasi, Revisi}

Pada fase ini dilakukan validasi tahap 2 terhadap bahan ajar elektronik yang telah dibuat. Proses validasi yang dilakukan terdiri dari dua jenis validasi yaitu validasi ahli materi dan validasi ahli media.

Hasil validasi yang dilakukan oleh masing-masing validator ahli dirangkum dari keseluruhan revisi dan disajikan pada Tabel 4.3.

Tabel 4.3 Saran Perbaikan oleh Masingmasing Validator dalam Validasi tahap 2

\begin{tabular}{|c|c|c|}
\hline NO. & NAMA & SARAN \\
\hline 1 & $\begin{array}{l}\text { Dr. Sugiarti, } \\
\text { M. Si. } \\
\text { (Dosen } \\
\text { Jurusan } \\
\text { Kimia } \\
\text { UNM) }\end{array}$ & $\begin{array}{cl}\text { Sebagai ahli materi: } \\
\text { - } & \text { Latar belakang } \\
\text { buku tidak usah } \\
\text { terlalu ramai } \\
\text { - } \quad \text { Tinjau kembali } \\
\text { Indikator pada } \\
\text { setiap aspek } \\
\text { yang dinilai }\end{array}$ \\
\hline 2 & $\begin{array}{l}\text { Dr. } \\
\text { Nurhikmah } \\
\text { H., S.Pd., } \\
\text { M. Si. } \\
\text { (Ketua } \\
\text { Program } \\
\text { Studi } \\
\text { Teknologi } \\
\text { Pendidikan } \\
\text { Program } \\
\text { Pascasarjana } \\
\text { UNM) }\end{array}$ & $\begin{array}{l}\text { Sebagai ahli media: } \\
\text { - Jangan } \\
\text { menggunakan } \\
\text { tulisan warna } \\
\text { merah ganti } \\
\text { dengan biru atau } \\
\text { hitam tebal } \\
\text { - } \text { Berikan variasi } \\
\text { tombol navigasi } \\
\text { Tambahkan } \\
\text { petunjuk } \\
\text { penggunaan } \\
\text { Cantumkan SK- } \\
\text { KD } \\
\text { Tambahkan tata } \\
\text { suara }\end{array}$ \\
\hline
\end{tabular}

Pada fase ini dilakukan beragam revisi dan evaluasi serta testing beta menurut pengembangan media Luther yaitu uji coba pertama skala kecil dari sisi pengguna atau pemakai aplikasi bahan ajar elektronik yang terdiri dari 10 orang peserta didik.

Setelahnya, kembali dilakukan validasi demi penyempurnaan bahan ajar elektronik sehingga diperoleh Prototipe 3: bahan ajar elektronik Science Flashbook mata pelajaran IPA kelas VIII SMP.

\section{e. Fase Implementasi}

Pembelajaran dilakukan sebanyak $3 \mathrm{x}$ pertemuan yang diakhiri dengan post-test hasil belajar serta pengisian angket oleh masing-masing peserta didik.

1) Hasil Respon Peserta Didik

Hasil analisis deskriptif respon peserta didik terhadap Science Flashbook pada materi Partikel disajikan pada Tabel 4.4.

Tabel 4.4 Hasil Angket Respon Peserta

Didik terhadap Science Flashbook

\begin{tabular}{|c|c|c|c|c|}
\hline No & Nilai & Kategori & $\begin{array}{l}\text { Fre } \\
\text { kue } \\
\text { nsi }\end{array}$ & $\begin{array}{l}\text { Persent } \\
\text { ase }(\%)\end{array}$ \\
\hline 1 & $85-100$ & $\begin{array}{c}\text { Sangat } \\
\text { Baik }\end{array}$ & 3 & 15 \\
\hline 2 & $65-84$ & Baik & 14 & 70 \\
\hline 3 & $55-64$ & $\begin{array}{c}\text { Kurang } \\
\text { Baik }\end{array}$ & 2 & 10 \\
\hline 4 & $35-54$ & $\begin{array}{l}\text { Tidak } \\
\text { Baik }\end{array}$ & 1 & 5 \\
\hline 5 & $0-34$ & $\begin{array}{c}\text { Sangat } \\
\text { Tidak } \\
\text { Baik }\end{array}$ & 0 & 0 \\
\hline
\end{tabular}

Hasil angket respon peserta didik menunjukkan bahwa peserta didik yang merespon Science Flashbook dengan kategori baik sebesar $70 \%$ dan peserta didik yang merespon dengan kategori sangat baik sebesar $15 \%$.

Hasil respon peserta didik diperkuat pula dengan analisis deskriptif respon 
pendidik terhadap Science Flashbook dengan hasil penilaian positif sebesar $87 \%$ yang berada pada kategori sangat baik.

2) Hasil Belajar Peserta Didik

Hasil analisis belajar IPA peserta didik kelas VIII SMPIT Al Biruni pada materi Partikel diperoleh dengan memberikan soal evaluasi berupa pilihan ganda di akhir pembelajaran. Data statistik secara lengkap disajikan pada Tabel 4.5.

Tabel 4.5 Analisis Hasil Belajar Peserta Didik

\begin{tabular}{|c|c|}
\hline Data & Nilai Statistik \\
\hline Jumlah Sampel & 20 \\
\hline Skor Total & 100 \\
\hline Skor Terendah & 52 \\
\hline Skor Tertinggi & 100 \\
\hline Skor Rata-Rata & 81,4 \\
\hline Sampel Tuntas & 16 \\
\hline Sampel Tidak Tuntas & 4 \\
\hline Ketuntasan (\%) & $80 \%$ \\
\hline
\end{tabular}

Analisis hasil belajar peserta didik setelah kegiatan pembelajaran menggunakan Science Flashbook secara keseluruhan menunjukkan bahwa telah memenuhi kriteria ketuntasan minimal dengan skor rata-rata peserta didik 81,4 dan perentase ketuntasan $80 \%$. Data tersebut juga menunjukkan bahwa bahan ajar elektronik yang dikembangkan memenuhi kriteria efektif sebab lebih besar dari atau sama dengan $80 \% \quad(\geq 80 \%)$ siswa mencapai ketuntasan.

Pada fase ini telah diperoleh rancangan akhir bahan ajar elektronik yang telah dapat memasuki tahap distribution pada teori pengembangan media oleh Luther dan sehingga dihasilkan Prototipe Final: bahan ajar elektronik Science Flashbook mata pelajaran IPA kelas VIII SMP.

\section{Kualitas Bahan Ajar Elektronik Science Flashbook Mata Pelajaran IPA}

Validitas bahan ajar elektronik divalidasi oleh dua ahli yang terdiri dari ahli materi dan ahli media. Validitas akan ditentukan dengan mencocokkan rata-rata total validitas seluruh butir penilaian dengan hasil peniliaian seperti tertera pada Tabel 4.6.

Tabel 4.6 Validasi Buku Elektronik oleh Para Ahli

\begin{tabular}{|c|c|c|c|}
\hline No & Bidang Telaah & $\bar{V}$ & Keterangan \\
\hline 1 & $\begin{array}{c}\text { Kualitas } \\
\text { Tampilan }\end{array}$ & 4,16 & SV \\
\hline 2 & Daya Tarik & 3,87 & SV \\
\hline 3 & Pokok Bahasan & 3,40 & V \\
\hline 4 & Kebahasaan & 4,75 & SV \\
\hline 5 & Penyajian & 3,00 & V \\
\hline \multicolumn{2}{|c|}{ Rata-rata } & 3,83 & SV \\
\hline
\end{tabular}

Penilaian yang dilakukan oleh ahli media dan ahli materi menunjukkan bahwa buku elektronik Science Flashbook termasuk dalam kategori "Sangat Valid" dengan rentang $3,5 \leq V \leq 4$.

Hasil analisis deskriptif respon peserta didik terhadap Science Flashbook pada materi Partikel seperti disajikan pada Tabel 4.4 di atas menunjukkan bahwa peserta didik yang merespon Science Flashbook dengan kategori baik sebesar $70 \%$ dan peserta didik yang merespon dengan kategori sangat baik sebesar $15 \%$.

Keefektifan produk dilihat dari keterlaksanaan aktivitas dalam kegiatan pembelajarans serta hasil belajar yang diperoleh peserta didik setelah proses pembelajaran. Berdasarkan analisis data terhadap aktivitas peserta didik, keseluruhan kategori terpenuhi dan terlaksana dengan baik seperti yang terlihat pada Tabel 4.7.

Tabel 4.7 Keterlaksanaan Aktivitas Peserta Didik

\begin{tabular}{|c|l|c|}
\hline No & \multicolumn{1}{|c|}{ Aktivitas } & Keterlaksanaan \\
\hline 1 & $\begin{array}{l}\text { Memperhatikan } \\
\text { informasi dan } \\
\text { mencatat seperlunya }\end{array}$ & $\sqrt{ }$ \\
\hline
\end{tabular}




\begin{tabular}{|c|l|c|}
\hline 2 & $\begin{array}{l}\text { Mengakses/membaca } \\
\text { materi pelajaran }\end{array}$ & $\sqrt{ }$ \\
\hline 3 & $\begin{array}{l}\text { Aktif terlibat dalam } \\
\text { tugas }\end{array}$ & $\sqrt{ }$ \\
\hline 4 & $\begin{array}{l}\text { Aktif berdiskusi } \\
\text { dengan teman }\end{array}$ & $\sqrt{ }$ \\
\hline 5 & $\begin{array}{l}\text { Mencatat apa yang } \\
\text { disampaikan } \\
\text { teman/guru }\end{array}$ & $\sqrt{ }$ \\
\hline 6 & $\begin{array}{l}\text { Mengajukan } \\
\text { pertanyaan kepada } \\
\text { teman/guru }\end{array}$ & $\sqrt{ }$ \\
\hline 7 & $\begin{array}{l}\text { Menjawab/ } \\
\text { menanggapi } \\
\text { pertanyaan } \\
\text { teman/guru }\end{array}$ & $\begin{array}{l}\text { Memberi bantuan } \\
\text { penjelasan kepada } \\
\text { teman yang } \\
\text { membutuhkan }\end{array}$ \\
\hline
\end{tabular}

Terlaksananya seluruh akivitas peserta didik dalam pembelajaran menunjukkan produk bahan ajar elektronik yang dihasilkan memenuhi kriteria efektif karena aktivitas peserta didik telah memenuhi kategori minimal $70 \%$ aspek yang diamati.

Selanjutnya, hasil belajar peserta didik secara individu dianalisis menggunakan analisis persentase skor benar dari seluruh butir tes. Penentuan ketuntasan belajar siswa akan didasarkan pada Kriteria Ketuntasan Minimum (KKM) yang telah ditetapkan oleh pendidik pada mata pelajaran IPA yaitu 75. Media pembelajaran yang dikembangkan telah memenuhi kriteria efektif karena lebih besar dari atau sama dengan $80 \%$ ( $\geq 80 \%)$ peserta didik mencapai ketuntasan.

\section{Pembahasan Hasil Penelitian}

a. Proses Pengembangan Bahan Ajar Elektronik Science Flashbook Mata Pelajaran IPA

Investigasi awal bertujuan untuk mengumpulkan informasi dan mengidentifikasi masalah melalui observasi dan analisis konsep. Pengumpulan informasi dilakukan dengan wawancara sehingga diperoleh hasil di mana pendidik masih jarang menggunakan sarana dan prasarana yang tersedia di sekolah karena kurangnya waktu mempersiapkan. Hal ini menyebabkan peserta didik kurang termotivasi dan kurang aktif dalam belajar IPA meskipun dalam proses pembelajaran pendidik telah melakukan berbagai variasi model pembelajaran namun masih dianggap perlu inovasi yang baru agar peserta didik tertarik untuk membaca buku paket dan terlibat aktif dalam kelas. Berdasarkan analisis tersebut, gagasan pengembangan sebuah bahan ajar elektronik diharapkan menjadi solusi.

Pada fase Desain dilakukan desain terhadap ide dan gagasan yang telah dibuat sehingga dihasilkan rancangan media ajar atau bahan ajar dalam hal ini bahan ajar elektronik yang diberi nama Science Flashbook dengan jabaran Science menandakan jenis materi ajar dalam buku tersebut Flashbook terdiri dari dua kata Flash yang berarti "Cahaya" atau "Kilatan" atau sederhananya menandakan suatu objek yang bergerak cepat dan Book berarti buku, dengan harapan buku elekronik ini menjadi buku sains yang dapat memberi informasi dengan cepat dan mudah diserap oleh siswa. Di tahap ini dilakukan pengolahan konsep (Concept) sesuai tahapan pengembangan media oleh Luther menjadi sebuah desain bahan ajar yang dapat dikembangkan di dalam aplikasi Adobe Indesign CS6 mulai dari eksistensi aplikasi, platform yang dapat menjalankan aplikasi, komponen-komponen bahan ajar elektronik mulai dari desain sampul, bagian pengantar dan daftar isi, latar gambar, media pendukung, materi-materi yang relevan, serta komponen penting lainnya yang diperlukan untuk mengatasi masalah dan memenuhi kebutuhan peserta didik. Setelah dilakukan penyempurnaan konsep selanjutnya adalah tahapan penyempurnaan desain (Design). Selama perancangan desain diperlukan keputusan yang matang terkait basis aplikasi yang digunakan untuk mewujudkan bahan ajar elektronik sesuai harapan. Adobe Inc. serta berbagai pengembang aplikasi media editing menyediakan ragam software yang dapat 
mendukung perancangan dan pembuatan buku elektronik sampai akhirnya dipilihlah Adobe Indesign CS6 sebagai basis pembuatan bahan ajar elektronik Science Flashbook. Alasan dipilihnya Adobe Indesign CS6 adalah karena aplikasi ini telah menyediakan alat (tools) yang lengkap yang dasarnya memang diperuntukkan dan banyak digunakan untuk pembuatan majalah online sehingga untuk membuat sebuah buku elektronik dinilai tidak akan sulit dan tidak sampai melakukan proses coding perintah dan hal-hal lain untuk menghasilkan fungsi-fungsi yang dibutuhkan oleh sebuah bahan ajar elektronik. Pada fase realisasi/konstruksi dilakukan eksekusi terhadap rancangan desain yang telah dibuat di fase sebelumnya. Selama proses konstruksi, tidak sedikit dari konsep desain awal yang dirancang berubah dan berkembang sesuai kebutuhan. Di fase ini digunakan aplikasi editing tambahan untuk mendukung desain bahan ajar elektronik seperti Corel Draw X7 sebagai alat editing gambar latar dan berbagai gambar yang dibutuhkan, Vegas Pro 14 sebagai alat editing video dan audio serta berbagai aplikasi bawaan Windows yang keseluruhan hasilnya dipadukan dan dieksekusi kembali di basis aplikasi Adobe Indesgin CS6. Pada fase konstruksi ini telah dilakukan tahapan assembly pada proses pengembangan media sehingga dihasilkan sebuah aplikasi bahan ajar elektronik yang dapat dijalankan di perangkat komputer, laptop, dan tablet yang menggunakan sistem operasi Windows. Sifat eksistensi dari bahan ajar elektronik yang dihasilkan adalah swf yang dapat dijalankan menggunakan Adobe Flash Player yang telah tersedia di setiap perangkat dan dapat diperbarui sesuai kebutuhan aplikasi. Fase konstruksi bahan ajar elektronik tak lepas dari peran validator ahli media dan ahli materi yang memberikan berbagai saran dan masukan demi kesempurnaan produk yang dihasilkan.

Pada tahap ini dilakukan testing versi alpha, yaitu pengujian aplikasi bahan ajar elektronik dari lingkungan pengembang dibantu oleh validator ahli untuk menguji penerapan media pada alat elektronik dan melihat bagian-bagian yang masih perlu direvisi.

Pada fase Tes, Evalusi, Revisi, produk yang telah dihasilkan secara konsisten terus dilakukan pengujian pengperasian aplikasi seperti cara menjalankan aplikasi, proses perpindahan setiap halaman, pengoperasian video, dan kemampuan bahan ajar elektronik untuk berjalan di berbagai perangkat. Selama fase ini pula diperoleh berbagai masukan dari validator dalam validasi tahap 2 terkait bahan ajar elektronik yang telah dikembangkan seperti menambahkan atau mengganti warna huruf yang digunakan pada nama tokoh dan istilah penting, menambahkan tombol navigasi yang dapat memudahkan pengguna untuk berpindah dari satu bagian ke bagian lainnya, menambahkan audio yang dapat memberikan kenyamanan belajar bagi peserta didik, serta membuat buku petunjuk penggunaan aplikasi. Saran-saran tersebut membuat bahan ajar elektronik tampil lebih menjanjikan setelah proses revisi. Hasil rancangan final untuk bahan ajar elektronik Science Flashbook mata pelajaran IPA diperoleh setelah melewati ragam revisi dan dianggap valid oleh validator ahli serta disetujui untul melanjutkan proses pengembangan tahapan berikutnya. Sejalan dengan proses pengembangan media oleh Luther, maka pada tahap ini dilakukan testing beta yaitu uji coba pada sisi pemakai atau pengguna aplikasi dalam hal ini dilakukan uji coba skala kecil. Diperoleh hasil yang memuaskan di mana peserta didik memberikan respon baik terhadap bahan ajar elektronik yang dikembangkan. Selanjutnya dilakukan revisi dan validasi kembali terkait kendala-kendala yang diperoleh selama testing beta demi penyempurnaan bahan ajar elektronik.

Fase Implementasi adalah tahap akhir dari seluruh tahapan dalam model pengembangan Plomp. Bahan ajar elektronik yang telah dievaluasi dan direvisi kemudian diproduksi dalam bentuk perangkat lunak 
(software) untuk diuji coba. Uji coba dilakukan untuk menuntaskan penilaian terhadap bahan ajar elektronik yang dikembangkan yaitu melihat kualitas media dari segi kevalidan, kepraktisan, dan keefektifan. Uji coba produk dalam hal ini bahan ajar elektronik bernama Science Flashbook dilakukan pada peserta didik kelas VIII SMPIT Al Biruni Makassar. Berdasarkan data investigasi awal pembelajaran yang dilakukan di SMPIT Al Biruni yang dilengkapi berbagai fasilitas masih kurang diintegrasikan dengan sarana yang ada yang menyebabkan beberapa peserta didik memiliki semangat belajar yang rendah. Motivasi membaca buku pelajaran oleh peserta didik juga tergolong sangat rendah sehingga pengembangan bahan ajar elektronik dinilai tepat untuk diterapkan pada kasus ini. Bahan ajar elektronik yang telah diuji kemudian dinilai dengan mengacu pada penilaian patokan terhadap standar kualitas yang telah ditentukan berdasarkan oleh data statistik. Hasil penilaian pada bahan ajar elektronik ini adalah valid, sehingga Science Flashbook telah merupakan produk akhir pada penelitian ini dan dapat digunakan serta dikembangkan menjadi lebih baik lagi.

\section{b. Kualitas Bahan Ajar Elektronik Science Flashbook Mata Pelajaran IPA}

Kualitas produk bahan ajar elektronik Science Flashbook mata pelajaran IPA kelas VIII SMP dibahas lebih rinci dengan mengacu pada kevalidan, kepraktisan, dan keefektifannya.

Proses validasi dilakukan untuk memperoleh masukan dan saran perbaikan selama pengembangan aplikasi hingga mendapatkan pengakuan "Valid" oleh masing-masing validator ahli terhadap produk yang dikembangkan. Penilaian kevalidan dilakukan menggunakan instrument angket dengan skala 1-5. Berdasarkan hasil uji kevalidan yang telah dilakukan dengan mengacu pada nilai statistik rata-rata 3,83 ; maka dapat disimpulkan bahwa bahan ajar elektronik yang dikembangkan adalah valid dan dapat digunakan sebagai media atau bahan ajar bagi pendidik dan peserta didik pada proses pembelajaran.

Respon positif berdasarkan angket yang telah diisi oleh siswa menunjukkan persentase yang sangat baik sebesar 15\% dan persentase baik sebesar $70 \%$, artinya persentase secara keseluruhan menunjukkan hasil yang positif sehingga dapat dinyatakan bahwa pengembangan bahan ajar elektronik Science Flashbook mata pelajaran IPA dalam hal ini pada materi Partikel (Atom, Ion, dan Molekul) telah memenuhi kategori praktis. Sejalan dengan respon peserta didik, pendidik juga memberikan respon positif terhadap Science Flashbook dengan persentase sebesar $87 \%$ pada kategori sangat baik. Pendidik beranggapan bahwa terobosan ini bisa menjadi salah satu solusi untuk menarik minat membaca peserta didik terhadap buku pelajaran. Pernyataan pada penelitian ini didukung oleh penelitian yang dilakukan Elis Siti Solihat yang mengembangkan buku elektronik jenis flipbook mengatakan bahwa terdapat respon positif dari peserta didik di mana hasil respon yang diperoleh yaitu sebesar $88 \%$ sehingga pengembangan buku elektronik layak untuk digunakan.

Berdasarkan analisis hasil belajar peserta didik kelas VIII SMPIT Al Biruni Makassar yang bertindak sebagai sampel penelitian diperoleh ketuntasan belajar sebesar $80 \%$ dari jumlah peserta didik sebanyak 20 orang bahkan dua orang peserta didik berhasil meraih nilai maksimal. Tingginya minat belajar peserta didik selama proses pembelajaran menjadi pemicu keberhasilan pencapaian ini. Hal ini menunjukkan bahwa bahan ajar yang dikembangkan memenuhi kriteria keefektifan. Acuan nilai keefektifan selanjutnya adalah keterlaksanaan aktivitas peserta didik harus minimal terhadap $70 \%$ aspek yang diamati. Terdapat 8 aktivitas peserta didik yang diamati, hal ini berarti 6 diantaranya harus terlaksana. Berdasarkan analisis data terhadap aktivitas peserta didik, 
keseluruhana kategori terpenuhi dan terlaksana dengan baik. Dengan demikian, dapat disimpulkan bahwa Science Flashbook sebagai bahan ajar elektronik dinilai efektif mengoptimalkan peserta didik dalam pembelajaran IPA terkhusus materi Partikel.

\section{SIMPULAN DAN SARAN}

Berdasarkan hasil penelitian, maka dapat disimpulkan sebagai berikut:

1. Pengembangan bahan ajar elektronik Science Flashbook IPA kelas VIII SMP pada Materi Pokok Partikel menggunakan model pengembangan Plomp yang terdiri dari lima fase yaitu fase investigasi awal mencakup observasi awal di sekolah; fase desain mencakup rancangan bahan ajar elektronik Science Flashbook; tahap reaslisasi/kontruksi mencakup realisasi rancangan bahan ajar elektronik Science Flashbook ke dalam aplikasi Adobe Indesign CS6; fase tes, evaluasi dan revisi mencakup validasi oleh validator ahli media dan ahli materi; dan fase implementasi mencakup uji coba bahan ajar elektronik Science Flashbook dalam proses pembelajaran.

2. Bahan ajar elektronik Science Flashbook yang dikembangkan memenuhi kategori "valid" dengan nilai rata-rata 3,83; memenuhi kategori "praktis" dengan persentase penilaian pendidik "sangat setuju" sebesar $85 \%$ dan untuk peserta didik "sangat setuju" sebesar 25,00\% dan "setuju" sebesar $68,75 \%$; dan memenuhi kategori "efektif" di mana ketuntasan hasil belajar peserta didik adalah $80 \%$ didukung pula dengan data aktivitas peserta didik di mana keseluruhan kategori aktivitas terlaksana dengan baik. Berdasarkan hasil kevalidan, kepraktisan, dan keefektifan tersebut, dapat disimpulkan bahwa pengembangan bahan ajar elektronik Science Flashbook dalam pembelajaran
IPA kelas VIII SMP terkhusus materi Partikel layak digunakan sebagai media serta buku ajar dalam pembelajaran.

Adapun saran:

1. Science Flashbook yang dikembangkan ini merupakan langkah awal untuk pengembangan sebuah bahan ajar elektronik IPA sehingga dipandang sangat perlu dilakukan penelitian lebih lanjut serta pengembangan ke arah yang lebih unggul seperti penambahan mata pelajaran lain seperti Fisika dan Biologi, kemudian dilakukan uji coba untuk subyek yang lebih luas.

2. Pengembangan bahan ajar elektronik Science Flashbook ke depannya agar melibatkan berbagai teknisi yang ahli di bidangnya sehingga bahan ajar elektronik Science Flashbook sebagai media pembelajaran dapat berjalan dengan baik.

\section{DAFTAR RUJUKAN}

Akker \& Plomp, 2013. Educational Design Research. Netherlands: SLO Netherlands Institute

Alfianika, Ninit. 2016. Metode Penelitian Pengajaran Bahasa Indonesia. Yogyakarta: Deepublish.

Anggraini, Widya Dwi, dkk. 2017. Pengembangan Perangkat Penilaian Kinerja Dan Sikap Pada Praktikum Titrimetri Dan Gravimetri SMKSMTI Makassar. Jurnal Chemistry Education Review (CER) Pendidikan Kimia PPs UNM, Vol. 1 No. 1 Hal. 35-44, September 2017.

Arifin, Syamsul dan Adi Kusrianto. 2009. Sukses Menulis Buku Ajar \& Referensi. Jakarta: Grasindo.

Asfiati. 2016. Pendekatan Humanis Dalam Pengembangan Kurikulum. Medan: Perdana Publishing.

Badan Penelitian dan Pengembangan Pusat Kurikulum. 2010. Bahan Pelatihan Pengembangan Pendidikan Budaya 
dan Karakter Bangsa. Jakarta: Kementerian Pendidikan Nasional.

Batubara, Hamdan Husein. 2018. Pembelajaran Berbasis Web dengan Moodle Versi 3.4. Yogyakarta: Penerbit Deepublish.

Benny, A.P. 2010. Model Desain Sistem Pembelajaran. Jakarta: Dian Rakyat.

Besari, Sahara M. 2008. Teknologi di Nusantara: 40 Abad Hambatan Inovasi. Jakarta: Penerbit Salemba Teknika.

Gora, Winastwan dan Sunarto. 2010. PAKEMATIK Strategi Pembelajaran Berbasis TIK. Jakarta: PT. Elex Media Komputindo.

Hakim, Rachmad S. 2010. Buku Pintar Windows 7. Jakarta: PT. Elex Media Komputindo.

Hobri. 2009. Metodologi Penelitian Pengembangan (Developmental Research), Aplikasi pada Penelitian Pendidikan Matematika. Jember: Proyek DIA-BERMUTU Program Pendidikan Matematika FKIP Universitas Jember.

Hidayat, Ahmad, dkk. Pengembangan Buku Elektronik Interaktif Pada Materi Fisika Kuantum Kelas XII SMA. Jurnal Pendidikan Fisika (JPF) Universitas Muhammadiyah Metro. Vol. 5, No. 2, September 2017.

Ichwan. 2015. Membuat Metode Pembelajaran Dengan Adobe Flash CS6. Yogyakarta: Penerbit ANDI.

Jodie, Putri. 2018. E-Book Kamu; Cara Membuat dan Menerbitkan E-Book Sendiri. Jakarta: JSP Book.

Kadir. Abdul. 1999. Konsep \& Tuntunan Praktis Basis Data. Yogyakarta: Penerbit ANDI.

Kementerian Negara Riset dan Teknologi Republik Indonesia. 2006. Penelitian, Pengembangan dan Penerapan Ilmu Pengetahuan dan Teknologi Bidang Sumber Energi Baru dan Terbarukan. Jakarta: Kemenristekdikti.

Krisno, Agus Moch, dkk. 2008. Ilmu Pengetahuan Alam Untuk SMP/MTs
Kelas VIII. Jakarta: Pusat Perbukuan Departemen Pendidikan Nasional.

OECD. 2015. PISA 2015 Result in Focus. Prancis: Secretary-General of the OECD.

Prabawanti, dkk. 2010. Panduan Praktis Mudah Beralih ke Windows 7. Semarang: Penerbit Andi dan Wahana Komputer.

Prihantini, Wahyu dkk. 2009. IPA Terpadu SMP Kelas VIII. Jakarta: Yudhistira.

Rochmad. 2012. Desain Model Pengembangan Perangkat Pembelajaran Matematika. Jurnal KREANO Vol. 3, No. 1, Juni 2012. Jurusan Matematika FMIPA UNNES.

Rusnilawati. 2017. Pengembanganbahan Ajar Elektronik (BAE) Berbantuan Flipbook berbasis Keterampilan Pemecahan Masalah Dengan Pendekatan CTL Pada Pembelajaran Matematika Kelas V Sekolah Dasar. Jurnal Profesi Pendidikan Dasar Vol. 4, No. 2, Desember 2017. UMS.

Rydberg, Terry. 2013. Exploring Adobe InDesign CS6. Canada: Delmar Engage Learning.

Saefullah, Ibnu. 2017. Membuat Buku Digital Mandiri. Jawa Barat: Kainoe Books.

Script, Island. 2008. Panduan Mudah Membuat Animasi. Jakarta Selatan: Mediakita.

Setyaningsih, dkk. 2008. Seri Profesional: Teknik Membuat Animasi dengan Adobe Flash CS3. Jakarta: Penerbit Salemba Infotek.

Setyosari, Punaji. 2013. Metode Penelitian Pendidikan \& Pengembangan. Jakarta: Prenadamedia Group.

Solihat, Elis Siti. Pengembangan Modul Elektronik (Flipbook) IPA Tipe Integrated Untuk Siswa Kelas VII Smp/Mts Dengan Tema Kalor Dalam Kehidupan. Online. http://digilib.uinsuka.ac.id/27998/. Publikasi Nasional Digital Library UIN Sunan Kalijaga. Diakses 02 Desember 2018. 
Sumar, Warni Tune dan Intan Abdul Razak. 2016. Strategi Pembelajaran dalam Implementasi Kurikulum Berbasis Soft Skill. Yogyakarta: Deepublish.

Sunyoto, Andi. 2010. Adobe Flash $+X M L=$ Rich Multimedia Application. Yogyakarta: Penerbit Andi.

Suparman, A. 1991. Desain Instruksional. Jakarta: Departemen Pendidikan dan Kebudayaan Direktorat Jenderal Pendidikan Tinggi.

Suryana, Dayat. 2012. Mengenal Teknologi. Yogyakarta: Cratespace

Susilana, Rudi dan Cepi Riyana. 2009. Media Pembelajaran. Bandung: CV Wacana Prima.

Sutatri, Tatik dan Edi Irawan. 2017. Kiat Sukses Meraih Hibah Penelitian Pengembangan. Yogyakarta: Deepublish Publisher.

Tompo, Basman. 2016. Cara Cepat Membuat Buku Digital Android. Malang: Matsnuepa Publishing.

Trianto. 2010. Mendesain Model Pembelajaran Inovatif-Progresif. Jakarta: Kencana.

UNESCO. 2016. Global Education Monitoring Report Education for People and Planet: Creating Sustainable Futures for All. Prancis: United Nation, Educational, Scientific and Cultural (UNESCO) Publishing.

Upu, H. 2010. Developing Mathematics Instructional Packages Using Stad Type Of Cooperative Model Of Grade Viii-2 Junior High School 30 Makassar. Online. (http://blog.unm.ac.id/hamzahupu/20 10/09/21/developing- mathema ticsinstructional-packages-using-stadtype-of-coopera tive-model-of-gradeviii-2-junior-high-school-30makassar/) Diakses 01 April 2017.

Vandestra, Muhammad. 2018. Panduan Cara Menginstall Windows 10 Untuk
Pemula Lengkap Dengan Gambar. Jakarta: Xenohikari D.

Wijayanto, dkk. 2016. Pengembangan Buku Sekoah Elektronik (BSE) Dilengkapi Media Evaluasi Mandiri Siswa Berbasis Portable Document Format. Jurnal Informatika UPGRIS Vol. 2, No. 2, Hal 83-89, Desember 2016.

Wulandari, Ika dkk. 2015. Pengembangan Buku Elektronik Trigonometri dengan Mengintegrasikan Penalaran Matematis, Teknologi, Sejarah, dan Aplikasi Trigonometri. Jurnal Elektronik Pembelajaran Matematika Vol. 3, No. 4, Hal 359-369, Juni 2015.

Zaki, Ali dan Smitdev Community. Cara Mudah Merakit PC. Jakarta: PT Elex Media Komputindo. 